\title{
MONOGRAFIE/MONOGRAPH
}

Valérie Tothová, Věra Hellerová (eds) (2021). Využití měřicích nástrojů v ošetřovatelství [Use of measuring instruments in nursing]. Praha. NLN, s. r. o. 225 s. ISBN 978-80-7422-817-9. DOI: 10.32725/zsf.2021.74228179

\section{Využití měřicích a hodnoticích nástrojů pro populaci starší 60 let}

kap. 5: DOI: 10.32725/zsf.2021.74228179.03

\section{Jitka Doležalová}

University of South Bohemia in České Budějovice, Faculty of Health and Social Sciences, Institute of Nursing, Midwifery and Emergency Care, České Budějovice, Czech Republic

\section{Souhrn}

Populace seniorů $(60+)$ bude $v$ budoucnu tvořit významnou část př́ijemců ošetřovatelské péče. $\checkmark$ rámci poskytování kvalitní, specializované a odborné péče je třeba jako podstatnou součást vnímat i práci s měřicími a hodnoticími nástroji, a především implementovat výsledky hodnocení i do samotné péče. Vzhledem k obsáhlé zdravotní problematice, která se postupem věku může rozvíjet, je nutné používat komplexní soubor nástrojů. V kapitole jsou zmapovány významné geriatrické syndromy jako sarkopenie a křehkost, kterým současné geriatrické ošetřovatelství nevěnuje dostatečnou pozornost. Potvrdili jsme ovšem i výskyt kognitivních poruch a nedostatečného nutričního stavu. Významné zjištění jsme také prokázali v oblasti kvality života a již vyjmenovaných syndromů. Jedná se pouze o část celkového problému, $v$ rámci ošetřovatelství je nutné např́klad působit i na oblast vzdělání sester pracujících s populací seniorů.

Klíčová slova: hodnoticí nástroje, kvalita života, populace starší 60 let, sarkopenie, vzdělání sester

\section{Podkapitoly:}

5.1 Významné zdravotní komplikace specifické pro populaci starší 60 let

5.2 Hodnocení křehkosti

5.2.1 Nástroje pro hodnocení křehkosti a prevalence

5.3 Hodnocení sarkopenie

5.3.1 Nástroje pro hodnocení sarkopenie a prevalence

5.4 Hodnocení nutričního stavu

5.4.1 Nástroje pro hodnocení nutrice a prevalence poklesu hmotnosti

5.5 Hodnocení intelektových poruch

5.5.1 Nástroje pro hodnocení kognitivních funkcí a prevalence kognitivních poruch

5.6 Monitorace sarkopenie, křehkosti, malnutrice a kognitivních poruch v ošetřovatelství

5.7 Postoj sester $k$ měřicím a hodnoticím nástrojům v péči o populaci starší 60 let

5.8 Vliv úrovně vzdělání na postoj sester k monitorování potřeb

5.9 Kvalita života u populace starší 60 let

\section{Literatura}

1. Abd Aziz, N. A. S., et al. (2017). Assessing the nutritional status of hospitalized elderly. Clin Interv Aging 12: 1615-1625. DOI: 10.2147/CIA.S140859. 
2. Bahat, G., et al. (2018). Performance of SARC-F in Regard to Sarcopenia Definitions, Muscle Mass and Functional Measures. J Nutr Health Aging 22(8): 898-903. DOI: 10.1007/s12603-018-1067-8.

3. Baum, J. I., et al. (2016). Protein Consumption and the Elderly: What Is the Optimal Level of Intake? Nutrients 8(6): 359. DOI: 10.3390/nu8060359.

4. Bell, S. P., et al. (2016). Geriatric Syndromes in Hospitalized Older Adults Discharged to Skilled Nursing Facilities. J Am Geriatr Soc 64(4): 715-722. DOI: 10.1111/jgs.14035.

5. Blackburn, P., et al. (2017). Depression in Older Adults: Diagnosis and Management. BCMJ. 59(3): 171177.

6. Bužgová, R., et al. (2013). Hodnotící nástroje pro zjištování potřeb pacientů v paliativní péči. Onkologie 7(6): 310-314.

7. Cary, M., Lyder, C. H. (2011). Geriatric assessment: Essential skills for nurses. American Nurse 1-3.

8. Clegg, A., et al. (2013). Frailty in elderly people. Lancet. 381(9868): 752-762. DOI: 10.1016/S01406736(12)62167-9.

9. Coker, R. H., Wolfe, R. R. (2012). Bedrest and sarcopenia. Curr Opin Clin Nutr Metab Care 15(1): 7-11. DOI: 10.1097/MCO.0b013e32834da629.

10. Cole, M., G. (2004). Delirium in elderly patients. Am J Geriatr Psychiatry 12(1): 7-21. DOI: 10.1176/foc.3.2.320.

11. Conroy, S., Elliott, A. (2017). The frailty syndrome. Medicine 45(1): 15-18. DOI: 10.1016/j.mpmed.2016.10.010

12. Cruz-Jentoft, A. J., et al. (2010). Sarcopenia: European consensus on definition and diagnosis. Age Ageing 39(4): 412-423. DOI: 10.1093/ageing/afq034.

13. Cruz-Jentoft, A. J., et al. (2014). Prevalence of and interventions for sarcopenia in ageing adults: a systematic review. Report of the International Sarcopenia Initiative (EWGSOP and IWGS). Age Ageing 43(6): 748-759. DOI: 10.1093/ageing/afu115.

14. Cruz-Jentoft, A. J., et al. (2019). Sarcopenia: revised European consensus on definition and diagnosis. Age Ageing 48(1): 16-31. DOI: 10.1093/ageing/afy169.

15. ČSÚ (2018). Senioři a zdraví. Demografický vývoj. [online] [cit. 2020-01-22]. Dostupné z: https://www.czso.cz/csu/czso/seniori-v-cr-v-datech-2018

16. Dementia (2020). World Health Organization (2019). Geneva: WHO, 2019. [online] [cit. 2020-01-22]. Dostupné z: https://www.who.int/news-room/fact-sheets/detail/dementia

17. Dent, E., et al. (2017). The Asia-Pacific Clinical Practice Guidelines for the Management of Frailty. J Am Med Dir Assoc 18(7): 564-575. DOI: 10.1016/j.jamda.2017.04.018.

18. Doležalová, J., Tóthová, V. (2019). Vybrané nástroje pro hodnocení geriatrické křehkosti. Geriatrie a gerontologie 8(3): 125-129.

19. Doležalová, J., et al. (2021). Impact of Selected Geriatric Syndromes on the Quality of Life in the Population Aged 60 and Older. Healthcare 9(6): 657. DOI: 10.3390/healthcare9060657.

20. Douglas, C., et al. (2014). What factors influence nurses' assessment practices? Development of the Barriers to Nurses' use of Physical Assessment Scale. J Adv Nurs 70(11): 2683-2694. DOI: 10.1111/jan.12408.

21. Ellis, G., Langhorne, P. (2005). Comprehensive geriatric assessment for older hospital patients. Br Med Bull 71: 45-59. DOI: 10.1093/bmb/ldh033.

22. Elsawy, B., Higgins, K. E. (2011). The geriatric assessment. Am Fam Physician 83(1): 48-56.

23. Engelheart, S., Brummer, R. (2018). Assessment of nutritional status in the elderly: a proposed functiondriven model. Food Nutr Res 17; 62. DOI: 10.29219/fnr.v62.1366.

24. European Delirium Association, American Delirium Society (2014). The DSM-5 criteria, level of arousal and delirium diagnosis: inclusiveness is safer. BMC Med 12: 141.

25. Evans, C. (2005). Malnutrition in the Elderly: A Multifactorial Failure to Thrive. Perm J 9(3): 38-41. DOI: 10.7812/tpp/05-056. 
26. Fletcher, K. (2012). Dementia. In: Boltz, M., Capezuti, E., Fulmer, T., et al. Evidence-based geriatric nursing protocols for best practice (pp. 163-185). New York, NY: Springer.

27. Folstein, M. F., et al. (1975). "Mini-mental state". A practical method for grading the cognitive state of patients for the clinician. J Psychiatr Res 12(3): 189-198. DOI: 10.1016/0022-3956(75)90026-6.

28. Frank, M., et al. (2015). Nutritional assessment in elderly care: a MUST! BMJ Qual Improv Rep 4(1): u204810.w2031. DOI: 10.1136/bmjquality.u204810.w2031.

29. Franková, V. (2007). Delirium ve vyšším věku. Psychiat pro Praxi 2(2): 56-59.

30. Fried, L. P., et al. (2001). Frailty in Older Adults: Evidence for a Phenotype. J Gerontol A Biol Sci Med Sci 56(3): M146-156. DOI: 10.1093/gerona/56.3.m146.

31. Gale, S. A., et al. (2018). Dementia. Am J Med 131(10): 1161-1169. DOI: 10.1016/j.amjmed.2018.01.022.

32. Greenberg, S. A. (2007). How to try this: the Geriatric Depression Scale: Short Form. Am J Nurs 107(10): 60-69; quiz 69-70. DOI: 10.1097/01.NAJ.0000292204.52313.f3.

33. Guigoz, Y. (2006). The Mini Nutritional Assessment (MNA) review of the literature - What does it tell us?. J Nutr Health Aging 10(6): 466-487.

34. Hajek, A., et al. (2017). Psychosocial correlates of unintentional weight loss in the second half of life in the German general population. PloS One 12(10): e0185749. DOI: 10.1371/journal.pone.0185749.

35. Hshieh, T. T., et al. (2018). Delirium in the Elderly. Psychiatr Clin North Am 41(1): 1-17. DOI: 10.1016/j.psc.2017.10.001.

36. Chern, C. J. H., Lee, S.-D. (2015). Malnutrition in hospitalized Asian seniors: An issue that calls for action. Journal of Clinical Gerontology and Geriatrics 6(3): 73-77. DOI: 10.1016/j.jcgg.2015.02.007

37. Ibrahim, K., et al. (2019). The feasibility of assessing frailty and sarcopenia in hospitalised older people: a comparison of commonly used tools. BMC Geriatr 19(1): 42. DOI: 10.1186/s12877-019-1053-y.

38. Inouye, S. K., et al. (2007). Geriatric Syndromes: Clinical, Research, and Policy Implications of a Core Geriatric Concept. J Am Geriatr Soc 55(5): 780-791. DOI: 10.1111/j.1532-5415.2007.01156.x.

39. Inouye, S. K., et al. (2014). Delirium in elderly people. Lancet. 383(9920): 911-922. DOI: 10.1016/S01406736(13)60688-1.

40. Jaul, E., Barron, J. (2017). Age-Related Diseases and Clinical and Public Health Implications for the 85 Years Old and Over Population. Front Public Health 5: 335. DOI: 10.3389/fpubh.2017.00335.

41. Jirák, R., Holmerová, I., Borzová, C., a kol. (2009). Demence a jiné poruchy paměti: komunikace a každodenní péče. Praha: Grada.

42. Jirák, R., et al. (2013). Gerontopsychiatrie. Praha: Galén, 350 s.

43. Kalvach, Z., et al. (2008). Geriatrické syndromy a geriatrický pacient. Praha: Grada

44. Karimlou, M., et al. (2011). Psychometric properties of the Persian version of the World Health Organization's quality of life questionnaire (WHOQOL-100). Arch Iran Med 14(4): 281-287.

45. Kaufer, D. I., et al. (2008). Cognitive screening for dementia and mild cognitive impairment in assisted living: comparison of 3 tests. J Am Med Dir Assoc 9(8): 586-593. DOI: 10.1016/j.jamda.2008.05.006.

46. Kirkwood, T. B. L. (2005). Understanding the Odd Science of Aging. Cell 120(4): 437-447. DOI: 10.1016/j.cell.2005.01.027.

47. Kondrup, J., et al. (2002). Nutritional risk screening (NRS 2002): a new method based on an analysis of controlled clinical trials. Clin Nutr 22(3): 321-336. DOI: 10.1016/s0261-5614(02)00214-5.

48. König, M., et al. (2017). Polypharmacy as a Risk Factor for Clinically Relevant Sarcopenia: Results From the Berlin Aging Study II. J Gerontol A Biol Sci Med Sci 73(1): 117-122. DOI: 10.1093/gerona/glx074.

49. Kozáková, R., Jarošová, D. (2010). Metody hodnocení stavu výživy seniorů. Med Pro Praxi 7(10): 396397.

50. Krishnamoorthy, Y., et al. (2018). Prevalence of malnutrition and its associated factors among elderly population in rural Puducherry using mini-nutritional assessment questionnaire. J Family Med Prim Care 7(6): 1429-1433. DOI: 10.4103/jfmpc.jfmpc_22_18. 
51. Kuckir, M., Vaňková, H., Holmerová, I., a kol. (2017). Vybrané oblasti a nástroje funkčního geriatrického hodnocení. Praha: Grada, 96 s.

52. Kumar, S. G., et al. (2014). Quality of Life (QOL) and Its Associated Factors Using WHOQOL-BREF Among Elderly in Urban Puducherry, India. J Clin Diagn Res 8(1): 54-57. DOI: 10.7860/JCDR/2014/6996.3917.

53. Kurita, Y., et al. (2019). Sarcopenia is a reliable prognostic factor in patients with advanced pancreatic cancer receiving FOLFIRINOX chemotherapy. Pancreatology 19(1): 127-135. DOI:

10.1016/j.pan.2018.11.001.

54. Kurlowicz, L. (1999). The Geriatric Depression Scale (GDS). J Gerontol Nurs 25(7): 8-9. DOI: 10.3928/0098-9134-19990701-09.

55. LaMantia, M. A., et al. (2016). Patterns of Emergency Department Use Among Long-Stay Nursing Home Residents With Differing Levels of Dementia Severity. J Am Med Dir Assoc 17(6): 541-546. DOI: 10.1016/j.jamda.2016.02.011.

56. Lee, H., et al. (2020). Frailty and Comprehensive Geriatric Assessment. J Korean Med Sci 35(3): e16. DOI: 10.3346/jkms.2020.35.e16.

57. Leistra, E., et al. (2013). Validity of nutritional screening with MUST and SNAQ in hospital outpatients. Eur J Clin Nutr 67(7): 738-742. DOI: 10.1038/ejcn.2013.85.

58. Ligthart-Melis, G. C., et al. (2020). Frailty, Sarcopenia, and Malnutrition Frequently (Co-)occur in Hospitalized Older Adults: A Systematic Review and Meta-analysis. J Am Med Dir Assoc 21(9): 12161228. DOI: 10.1016/j.jamda.2020.03.006.

59. Lim, S.-K., et al. (2020). Association between sarcopenia and fall characteristics in older adults with fragility hip fracture. Injury 51(11): 2640-2647. DOI: 10.1016/j.injury.2020.08.031.

60. Little, R.D., et al. (2017). Compensatory anabolic signaling in the sarcopenia of experimental chronic arthritis. Sci Rep 7: 6311. DOI: 10.1038/s41598-017-06581-6.

61. Malá, E., et al. (2011). Výživa ve stáří. Interní Med 13(3): 111-116.

62. Malmstrom, T. K., Morley, J. E. (2013). SARC-F: A Simple Questionnaire to Rapidly Diagnose Sarcopenia. J Am Med Dir Assoc 14(8): 531-532. DOI: 10.1016/j.jamda.2013.05.018.

63. Malmstrom, T. K., et al. (2016). SARC-F: a symptom score to predict persons with sarcopenia at risk for poor functional outcomes. J Cachexia Sarcopenia Muscle 7(1): 28-36. DOI: 10.1002/jcsm.12048.

64. Malmstrom, T. K., et al. (2015). The Rapid Cognitive Screen (RCS): A Point-of-Care Screening for Dementia and Mild Cognitive Impairment. J Nutr Health Aging 19(7): 741-744. DOI: 10.1007/s12603015-0564-2.

65. Mathew, A. C., et al.. (2016). Prevalence and correlates of malnutrition among elderly in an urban area in Coimbatore. Indian J Public Health 60(2): 112-117. DOI: 10.4103/0019-557X.184542.

66. Matusik, P., et al. (2012). Severe frailty and cognitive impairment are related to higher mortality in 12month follow-up of nursing home residents. Arch Gerontol Geriatr 55(1): 22-24. DOI: 10.1016/j.archger.2011.06.034.

67. McGowan, P. O., Szyf, M. (2010). Environmental epigenomics: understanding the effects of parental care on the epigenome. Essays Biochem 48(1): 275-287. DOI: 10.1042/bse0480275.

68. McMinn, J., et al. (2011). Investigation and management of unintentional weight loss in older adults. BMJ 342:d1732. DOI: 10.1136/bmj.d1732.

69. Milisen, K., et al. (2012). Assessing cognitive function. In: Boltz, M., Capezuti, E., Fumler, T., et al. Evidence-based geriatric nursing protocols for best practice. 4. vyd. New York (NY): Springer Publishing Company.

70. Mitnitski, A. B., et al. (2001). Accumulation of Deficits as a Proxy Measure of Aging. Sci World J 1: 323336. DOI: $10.1100 /$ tsw.2001.58.

71. Morley J. E. (2016). Frailty and Sarcopenia: The New Geriatric Giants. Rev Invest Clin 68(2): 59-67.

72. Morley, J. E. (2017a). Rapid Geriatric Assessment. Secondary Prevention to Stope Age- Associated Disability. Clin Geriatr Med 33(3): 431-440. DOI: 10.1016/j.cger.2017.03.006. 
73. Morley, J. E. (2017b). The New Geriatric Giants. Clin Geriatr Med 33(3): xi-xii. DOI: 10.1016/j.cger.2017.05.001.

74. Morley, J. E., Kraenzle, D. (1994). Causes of Weight Loss in a Community Nursing Home. J Am Geriatr Soc 42(6): 583-585. DOI: 10.1111/j.1532-5415.1994.tb06853.x.

75. Morley, J. E., et al. (2013). Frailty Consensus: A Call to Action. J Am Med Dir Assoc 14(6): 392-397. DOI: 10.1016/j.jamda.2013.03.022.

76. Muscaritoli, M., et al. (2010). Consensus definition of sarcopenia, cachexia and pre-cachexia: Joint document elaborated by Special Interest Groups (SIG) "cachexia-anorexia in chronic wasting diseases" and "nutrition in geriatrics". Clin Nutr 29(2): 154-159. DOI: 10.1016/j.clnu.2009.12.004.

77. Nasreddine, Z. S., et al. (2005). The Montreal Cognitive Assessment, MoCA: A Brief Screening Tool For Mild Cognitive Impairment. J Am Geriatr Soc 53(4): 695-699. DOI: 10.1111/j.1532-5415.2005.53221.x.

78. Nejati, V., Ashayeri, H. (2008). Health related quality of life in the elderly in Kashan. Iran J Psych Clin Psychol 14(1): 56-61.

79. Nieuwenhuis-Mark, R. E. (2010). The Death Knoll for the MMSE: Has It Outlived Its Purpose? J Geriatr Psychiatry Neurol 23(3): 151-157. DOI: 10.1177/0891988710363714.

80. Noguchi, N., et al. (2016). Prevalence of the geriatric syndromes and frailty in older men living in the community: The Concord Health and Ageing in Men Project. Australas J Ageing 35(4): 255-261. DOI: 10.1111/ajag.12310.

81. Norris, D. R., et al. (2016). The Mental Status Examination. Am Fam Physician 94(8): 635-641.

82. O'Halloran, A. M., et al. (2014). Sustained Attention and Frailty in the Older Adult Population. J Gerontol B Psychol Sci Soc Sci 69(2): 147-156. DOI: 10.1093/geronb/gbt009.

83. Olaroiu, M., et al. (2014). The psychometric qualities of the Groningen Frailty Indicator in Romanian community-dwelling old citizens. Fam Pract 31(4): 490-495. DOI: 10.1093/fampra/cmu022.

84. Overton, M., et al. (2019). Prevalence and Incidence of Mild Cognitive Impairment across Subtypes, Age, and Sex. Dement Geriatr Cogn Disord 47(4-6): 219-232. DOI: 10.1159/000499763.

85. Ozer, S., et al. (2016). A systematic review of the diagnostic test accuracy of brief cognitive tests to detect amnestic mild cognitive impairment. Int J Geriatr Psychiatry 31(11): 1139-1150. DOI: 10.1002/gps.4444.

86. Pahor, M., et al. (2009). Sarcopenia: Clinical evaluation, biological markers and other evaluation tools. J Nutr Health Aging 13(8): 724-728. DOI: 10.1007/s12603-009-0204-9.

87. Park, S.-C., et al. (2017). Screening for Depressive Disorder in Elderly Patients with Chronic Physical Diseases Using the Patient Health Questionnaire-9. Psychiatry Investig 14(3): 306-313. DOI: 10.4306/pi.2017.14.3.306.

88. Pilgrim, A. L., et al. (2017). Measuring appetite with the simplified nutritional appetite questionnaire identifies hospitalised older people at risk of worse health outcomes. J Nutr Health Aging 20(1): 3-7. DOI: 10.1007/s12603-015-0533-9.

89. Pokorná, A., a kol. (2013). Ošetřovatelství v geriatrii: hodnoticí nástroje. Praha: Grada, $202 \mathrm{~s}$.

90. Prince, M., et al. (2016). Recent global trends in the prevalence and incidence of dementia, and survival with dementia. Alzheimers Res Ther 8(1): 23. DOI: 10.1186/s13195-016-0188-8.

91. Raboch, J., Pavlovský, P., a kol. (2014). Psychiatrie. Praha: Karolinum.

92. Rasheed, S., Woods, R. T. (2013). Predictive validity of 'Malnutrition Universal Screening Tool' ('MUST') and Short Form Mini Nutritional Assessment (MNA-SF) in terms of survival and length of hospital stay. eSPEN J 8(2): e44-e50. DOI: 10.1016/j.clnme.2013.01.001.

93. Rashid, A. K., et al. (2012). Cognitive impairment among the elderly Malays living in rural Malaysia. Med J Malaysia 67(2): 186-189.

94. Razani, J., et al. (2009). Predicting Everyday Functional Abilities of Dementia Patients with the MiniMental State Examination. J Geriatr Psychiatry Neurol 22(1): 62-70. DOI: 10.1177/0891988708328217. 
95. Rockwood, K., Mitnitski, A. (2006). Limit to deficit accumulation in elderly people. Mech Ageing Def 127(5): 494-496. DOI: 10.1016/j.mad.2006.01.002.

96. Rockwood, K., et al. (2005). A global clinical measure of fitness and frailty in elderly people. CMAJ 173(5): 489-495. DOI: 10.1503/cmaj.050051.

97. Rosen, S. L., Reuben, D. B. (2011). Geriatric Assessment Tools. Mt Sinai J Med 78: 489-497. DOI: 10.1002/msj.20277.

98. Rosenberg, I. (1989). Summary comments: epidemiological and methodological problems in determining nutritional status of older persons. Am J Clin Nutr 50: 1231-1233. DOI: 10.1093/ajcn/50.5.1231.

99. Rossi, A. P., et al. (2017). Assessing the Risk of Sarcopenia in the Elderly: The Mini Sarcopenia Risk Assessment (MSRA) Questionnaire. J Nutr Health Aging 21(6): 743-749. DOI: 10.1007/s12603-017-09214.

100. Rossi, A. P., et al. (2021). Sarcopenia Risk Evaluation in a Sample of Hospitalized Elderly Men and Women: Combined Use of the Mini Sarcopenia Risk Assessment (MSRA) and the SARC-F. Nutrients 13(2): 635. DOI: 10.3390/nu13020635.

101. Sanford, A. M., et al. (2020). High prevalence of geriatric syndromes in older adults. PLoS One 15(6): e0233857. DOI: 10.1371/journal.pone.0233857.

102. Saragat, B., et al. (2012). Nutritional and psycho-functional status in elderly patients with Alzheimer's disease. J Nutr Health Aging 16(3): 231-236. DOI: 10.1007/s12603-011-0347-3.

103. Sheardová, K., Hudeček, D. (2011). Prevence demence a životní styl. Neurol praxi 12(6): 418-421.

104. Shimokata, H., Ando, F. (2012). Association of daily physical performance with muscle volume and strength. Nihon Ronen Igakkai Zasshi 49(2): 195-198. DOI: 10.3143/geriatrics.49.195.

105. Smith, K. L., Greenwood, C. E. (2008). Weight Loss and Nutritional Considerations in Alzheimer Disease. J Nutr Elder 27(3-4): 381-403. DOi: 10.1080/01639360802265939.

106. Sováriová Soósová, M. (2016). Determinants of quality of life in the elderly. Cent Eur J Nurs Midw 7(3): 484-493. DOI: 10.15452/CEJNM.2016.07.0019.

107. Spering, C. C., et al. (2012). Diagnostic Accuracy of the MMSE in Detecting Probable and Possible Alzheimer's Disease in Ethnically Diverse Highly Educated Individuals: An Analysis of the NACC Database. J Gerontol A Biol Sci Med Sci 67(8): 890-896. DOI: 10.1093/gerona/gls006.

108. Sternberg, S. A., et al. (2011). The Identification of Frailty: A Systematic Literature Review. J Am Geriatr Soc 59(11): 2129-2138. DOI: 10.1111/j.1532-5415.2011.03597.x.

109. Strauss, E., et al. (2006). A compendium of neuropsychological tests: Administration, norms, and commentary. New York: Oxford University Press.

110. Tamura, Y., et al. (2018). Prevalence of frailty, cognitive impairment, and sarcopenia in outpatients with cardiometabolic disease in a frailty clinic. BMC Geriatr 18(1): 264. DOI: 10.1186/s12877-018-0955-4.

111. Theou, O., Rockwood, K. (2012). Should frailty status always be considered when treating the elderly patient? Aging Health 8(3): 261-271. DOI: 10.2217/ahe.12.8.

112. Tkacheva, O. N., et al. (2018). Prevalence of geriatric syndromes among people aged 65 years and older at four community clinics in Moscow. Clin Interv Aging 13: 251-259. DOI: 10.2147/CIA.S153389.

113. Tomeš, I., Šámalová, K., a kol. (2017). Sociální souvislosti aktivního stáří. Praha: Univerzita Karlova, Karolinum, $256 \mathrm{~s}$.

114. Topinková, E. (2010). Geriatrie pro praxi. 2. vyd. Praha: Galén, 270 s.

115. Vahedi, S. (2010). World Health Organization Quality-of-Life Scale (WHOQOL-BREF): Analyses of Their Item Response Theory Properties Based on the Graded Responses Model. Iran J Psychiatry 5(4): 140153.

116. van den Bussche, H., et al. (2011). Which chronic diseases and disease combinations are specific to multimorbidity in the elderly? Results of a claims data based cross-sectional study in Germany. BMC Public Health 11: 101. DOI: 10.1186/1471-2458-11-101. 
117. van Kan, G. A., et al. (2008). Frailty: Toward a Clinical Definition. J Am Med Dir Assoc 9(2): 71-72. DOI: 10.1016/j.jamda.2007.11.005.

118. Waldron-Perrine, B., Axelrod, B. N. (2012). Determining an appropriate cutting score for indication of impairment on the Montreal Cognitive Assessment. Int J Geriatr Psychiatry 27(11): 1189-1194. DOI: 10.1002/gps.3768.

119. Weber, P. (2018). Stárnutí staré společnosti (seniorizace) a geriatrizace medicíny. Geriatrie a Gerontologie 7(4): 152-155.

120. Welsh, T. J., et al. (2014). Comprehensive geriatric assessment--a guide for the non-specialist. Int J Clin Pract 68(3): 290-293. DOI: 10.1111/ijcp.12313.

121. WHO (1995). Physical Status: the Use and Interpretation of Anthropometry: Report of a WHO Expert Committee. Geneva, Switzerland: World Health Organization.

122. WHO (2015). Global Action Against Dementia. WHO Document Production services. Geneva.

123. WHO (2017). WHO clinical consortium on healthy ageing: topic focus: frailty and intrinsic capacity: report of consortium meeting. Geneva, Switzerland.

124. WHO (2018). Ageing and health. [online] [cit. 2020-01-22]. Dostupné z: https://www.who.int/newsroom/fact-sheets/detail/ageing-and-health

125. WHO (2019). Dementia. [online] [cit. 2021-06-21]. Dostupné z: https://www.who.int/news-room/factsheets/detail/dementia

126. Wiltjer, H., Kendall, N. (2019). Assessment of older people 6: assessing the spiritual domain. Nursing Times 115(10): 24-27.

127. Winkler, I., et al. (2006). WHOQOL-OLD Group. Der WHOQOL-OLD -- Ein Fragebogen zur interkulturellen Erfassung der Lebensqualität im Alter [The WHOQOL-Old - A questionnaire for the intercultural measuring of quality of life in the elderly]. Psychother Psychosom Med Psychol 56(2): 63-69.

128. Woodford, H. J., George, J. (2007). Cognitive assessment in the elderly: a review of clinical methods. QJM 100(8): 469-484. DOI: 10.1093/qjmed/hcm051.

129. Xue Q.-L. (2011). The frailty syndrome: definition and natural history. Clin Geriatr Med. 27(1): 1-15. DOI: 10.1016/j.cger.2010.08.009.

130. Yang, M., et al. (2018). Screening Sarcopenia in Community-Dwelling Older Adults: SARC-F vs SARC-F Combined With Calf Circumference (SARC-CalF). J Am Med Dir Assoc 19(3): 277.e1-277.e8. DOI: 10.1016/j.jamda.2017.12.016. 